DOI: $10.31073 / \mathrm{mivg} 201801-113$

Available (PDF): http://mivg.iwpim.com.ua/index.php/mivg/article/view/113

УДК 631.67:626.95

\title{
ПАРАМЕТРИЧНА НАДІЙНІСТЬ МАТЕРИКОВОЇ ДІЛЯНКИ ПІВНІЧНО-КРИМСЬКОГО КАНАЛУ
}

\section{І.Л. Гончарук}

Інститут водних проблем і меліорації НААН, Київ,Україна;е-mail: gonch.irch@gmail.com

\begin{abstract}
Анотація. Розглянуто особливості функціонувания материкової частини ПівнічноКримського каналу в умовах припинення подачі води в Крим, використовуючи водомірні властивості підпірних та випускних гідротехнічних споруд. Наведено результати розрахунків параметричної надійності розподілу води в каналі. Проблеми иентралізованого управління витратами води на гідротехнічних спорудах в умовах, які не передбачені проектом та иляхи їх вирішення.
\end{abstract}

Ключові слова: магістральний канал, відповідні витрати води, водорозподіл, водооблік, параметрична надійність

Вступ. Параметричну надійність зрошувального каналу запропоновано оцінювати коефіцієнтом кореляції відповідних витрат води на гідротехнічних спорудах [1]. Збільшення коефіцієнта свідчить про посилення параметричної надійності.

Експлуатація материкової ділянки Північно-Кримського каналу (далі ПКК) відбувається в умовах послаблення параметричної надійності, виникнення підпірних явищ, унаслідок чого гідротехнічні споруди втрачають водомірні властивості.

Отже розроблення методів, способів та рекомендацій щодо управління режимом роботи Північно-Кримського каналу на території Херсонської області та удосконаленням водообліку є актуальним науково-прикладним питанням.

Мета роботи полягає в оптимізації режиму роботи гідротехнічних споруд каналу в умовах, не передбачених проектом його експлуатації, шляхом синхронізації відповідних витрат води на цих спорудах.

Теоретичні на експериментальні засади досліджень. Експлуатація каналу здійснюється шляхом централізованого диспетчерського управління витратами води на гідротехнічних спорудах. Мета управління полягає у синхронізації методом руслового водного балансу гідрографів стоку води через усі споруди, забезпеченні усталеного руху води, розподілу ії між споживачами «за потребою» чи «за планом», зарегулюванні в руслі каналу випадкових коливань витрат води, обумовлених технологічно виправданими чинниками, пов'язаними 3 часовою та просторовою неузгодженістю гідрографів подачі та забору води по довжині каналу.

Критерієм оптимізації $\epsilon$ параметрична надійність розподілу води в каналі [1]

Аналіз режиму роботи великих зрошувальних каналів самопливних зрошувальних систем України свідчить про те, що найбільш оптимальною тривалістю розрахункового періоду є одна доба [2]. Саме за добу здійснюеться повний цикл збурень у водозаборі 3 каналів або водоподачі в них, а вплив хвиль переміщення на середньодобову витрату води в каналі $\epsilon$ мінімальним.

Рівняння руслового водного балансу, яким можна описати розподіл води на ділянці каналу протягом однієї доби, матиме вигляд:

$$
Q_{i}=\left(Q_{i+1}+\sum q\right)+I \pm \Delta Q \pm \Delta,
$$

де $Q_{i}-$ середньодобова витрата води через $i$-ту підпірно-регулюючу гідротехнічну споруду, $\mathrm{M}^{3} / \mathrm{c}$, розташовану на початку обраної ділянки русла каналу;

$Q_{i+1}$ - середньодобова витрата води через споруду, розташовану у створі, що замикає цю ділянку, $\mathrm{M}^{3} / \mathrm{c}$;

$\Sigma_{q}-$ середньодобовий сумарний водозабір на ділянці каналу, $\mathrm{m}^{3} / \mathrm{c}$;

$I$ - середньодобові втрати води на фільтрацію і випаровування, $\mathrm{M}^{3} / \mathrm{c}$;

$\Delta Q$ - середньодобова зміна витрати води по довжині каналу, яка обумовлена накопиченням або спрацьовуванням ії об'єму в руслі каналу, $\mathbf{m}^{3} / \mathrm{c}$;

$\Delta$ характеризує абсолютну величину відхилення фактичної витрати води через підпірнорегулюючу гідротехнічну споруду від техно- 
логічно обгрунтованої витрати води, що задається на етапі планування (прогнозування) гідрографу стоку води через $i$-ту ПС (при $\Delta \rightarrow 0$ якість розподілу води підвищується, величина iii залежить також від похибки градуювання споруд).

Рівняння (1) можна розглядати як лінійну функцію виду $Y=a X \pm b$, де: $Y=Q_{i}$; $X=\left(Q_{i+1}+\sum q\right) ; b=(I+\Delta Q+\Delta)$

Втрати води у Північно-Кримському магістральному каналі змінюються протягом доби та по місяцях, але в середньому за добу їх можна вважати постійною величиною [3].

Інформаційною базою обраного методу досліджень є строкові рівні води, висота відкриття затворів та витрати води на гідротехнічних спорудах [4]. Іх містять журнали диспетчерської служби Управління ПівнічноКримського каналу. Дані вносять у журнали кожні 4 години, починаючи 3 нуля годин.

Режим роботи материкової частини каналу. Материкова частина ПівнічноКримського каналу простягається від гідротехнічної споруди в голові каналу до нещодавно збудованої споруди на 107,3 кілометрі каналу. Дотепер материкову частину каналу замикав створ на так званому балансовому посту на 96 кілометрі, на якому велись спостереження за обсягами водоподачі в АР Крим та вимірювання витрат води для градуювання цієї ділянки русла.

Під час подачі води в Крим розподіл їі на ділянці Північно-Кримського магістрального каналу від головної споруди до першої перекачувальної насосної станції (HC-1) здійснювався диспетчерами за схемою верхнього б’єфа [5]. За такого управління всі надлишки води, що формувались на ділянці каналу протяжністю 208,1 кілометрів, самопливом надходили до аванкамери $\mathrm{HC}-1$, а далі

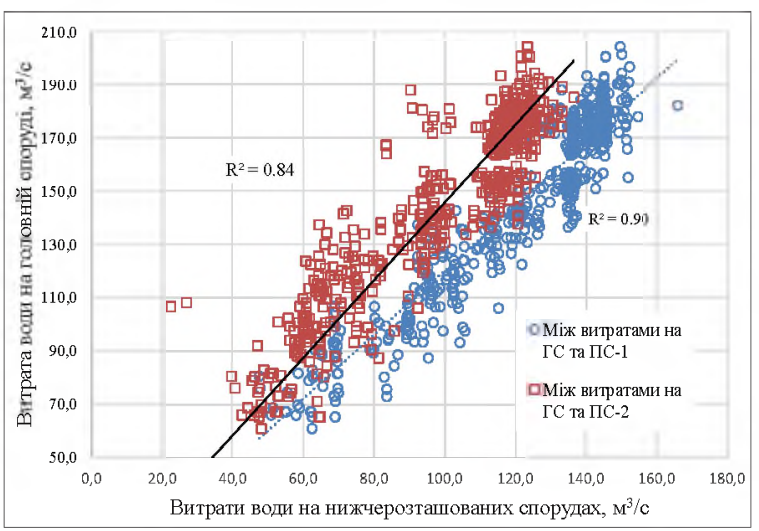

Рис. 1. Параметрична надійність розподілу води у ПКК у 2001 p. використовувались на подачу води у низку каналів другого порядку та підкачувальним насосним станціям.

Рис. 1 свідчить про тісний кореляційний зв'язок $\left(\mathrm{R}^{2}\right)$ між витратами води на спорудах ГС та ПС-1, а також ГС та ПС-2 у 2001 р. Таким чином, у минулому, принаймні на ділянці Північно-Кримського каналу від головної споруди до ПС-2 (Красноперекопськ), підтримувалась достатньо значуща параметрична надійність розподілу води.

Після припинення подачі води в АР Крим схема управління водорозподілом на материковій (77,8 км) ділянці каналу від головної споруди до першої підпірної споруди (ПС-1) залишилась без змін. Нижче за течією від ПС-1 до ПК-107 утворилась тупикова ділянка протяжністю 29,2 км. Забір води здійснюється переважно каналами РМ-1 та РМ-2.

На рис. 2 видно що, за таких умов параметрична надійність розподілу води на ділянці ПКК від головної споруди до ПК-107 суттєво послабшала, про що свідчать значення коефіцієнтів кореляції між рядами середньодобових витрат води на головній споруді та ПС-1.

Управління подачею води на ділянку каналу нижче ПС-1 доцільно ув'язати 3 режимом роботи головної споруди. До того ж, важливо, аби зміна рівня та витрат води на сьогодні «(тупиковій» ділянці каналу була мінімальною i не перевищувала середньоквадратичної похибки визначення витрати води на ПС-1, a саме 4-6\% від середньодобової витрати води, яка буде проходити через споруду.

Режим роботи головної споруди каналу за різного попиту на воду. Багаторічна експлуатація Північно-Кримського магістрального каналу, в тому числі останніми 2014-2017 роками, свідчить, що витрати води через головну споруду, а також споруди ПС-1,

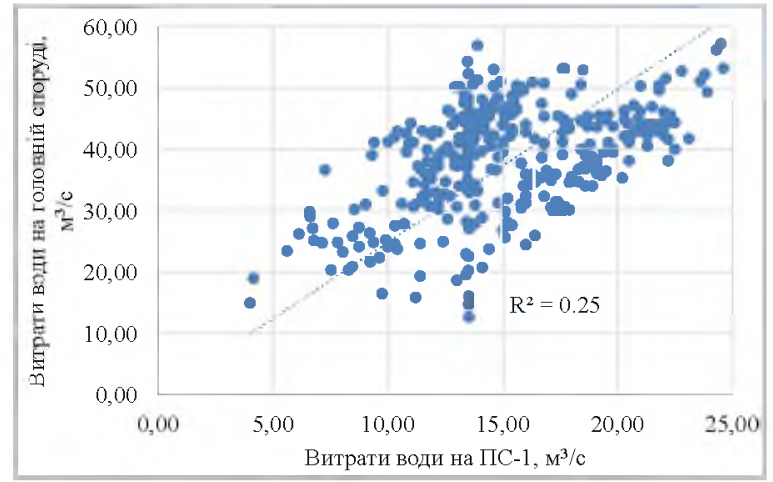

Рис. 2. Параметрична надійність розподілу води на материковій ділянці ПКК у 2015-2017 роках 
ПС-2 найбільш тісно корелюють 3 висотою відкриття затворів (коефіцієнт кореляції коливається від 0,73 до 0,98 ).

За умов параметрично надійного водорозподілу зміна витрат води на головній споруді Північно-Кримського магістрального каналу за певний час призводить до зміни режиму роботи всіх нижче розташованих за течією споруд, принаймні 3 самопливним водозабором, тому що змінюеться рівень води в їхніх б'єфах, напір на водозливній частині затвору, а відтак і витратні характеристики споруд. Зазвичай, зростання рівня веде до зростання витрат і навпаки.

Це дає підстави скористатись показниками параметричної надійності для прогнозування необхідної водоподачі в голові ПКК за плановими чи вже відомими середньодобовими витратами води на головній споруді Краснознам'янського каналу (ПК61), підпірно-регулювальній споруді ПС-1 та головних спорудах каналів РM-1 та PM-2.

Більш детальний ретроспективний аналіз даних засвідчив тісну кореляцію середньодобових витрат води на головній споруді з сумою відповідних середньодобових витрат води на головних спорудах Краснознам'янского каналу, каналах РМ-1 та РМ-2 (рис. 3)

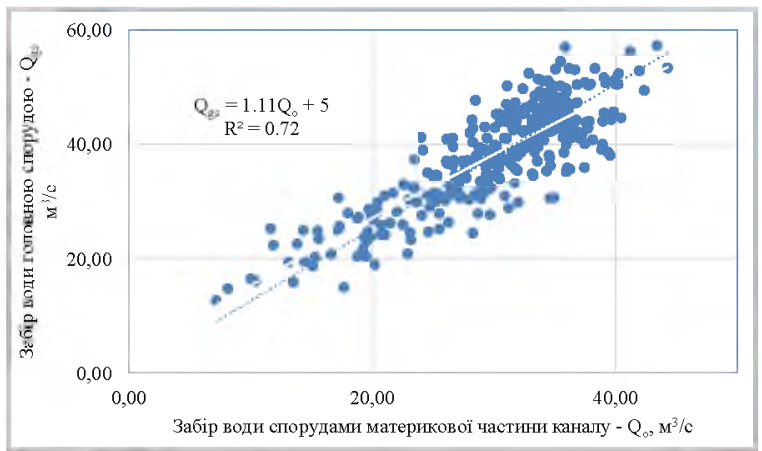

Рис. 3. Залежність витрат води на головній споруді ПКК від сумарного забору води спорудами на 61 км, PM-1 та РМ-2
Стандартне відхилення розрахункових витрат води від табличних становить $9,7 \mathrm{~m}^{3} / \mathrm{c}$, що може призвести до зміни рівня води в каналі на 12 см за добу, або лише на 3 см між черговим регулюванням споруд [6]. Часу достатньо, щоб уникнути переповнення русла каналу водою.

Таким чином, практичним результатом наведених підсумків досліджень $\epsilon$ методика централізованого диспетчерського управління гідротехнічними спорудами, спрямована на синхронізацію їх гідрографів.

Інженерні рішення на підтримку технологічних схем розподілення води на материковій частині каналу. Докорінні зміни умов розподілу води обумовлюють спектр можливих інженерних рішень, спрямованих на оптимізацію експлуатаційного режиму роботи гідротехнічних споруд ПКК.

Гідротехнічні споруди доцільно оснащувати засобами прямого обліку води по аналогії з головною водозабірною спорудою Краснознам'янського каналу. Лише це дозволить організувати технологічний та комерційний облік води.

Необхідно також провести комплекс робіт 3 градуювання всіх гідротехнічних споруд 3 уточненням методики розрахунку руслового водного балансу ПКК.

Висновки. Результати оцінки параметричної надійності материкової ділянки ПКК свідчать, що найбільш доцільним є централізоване диспетчерське управління русловим водним балансом за короткі інтервали часу 3 врахуванням наявних кореляційних зв'язків між відповідними витратами води на гідротехнічних спорудах.

Материкову ділянку каналу рекомендується вважати суцільним б'єфом і регулювати режим його роботи, змінюючи витрати води на головній споруді. Витрати води на ПС-1 вважати фактором, обмежуючим надходження води на «тупикову» ділянку.

\section{Бібліографія}

1. Михайлов Ю.О., Кочаровська І.Л., Попович А.В. Параметрична надійність водорозподілу у Північно-Кримському каналі. Меліорація і водне господарство. 2003; вип. 89. С. 66-71.

2. Коваленко П.І., Михайлов Ю.О. Раціональне використання води при зроменні. Київ: Аграрна наука, 2000. $154 \mathrm{c}$.

3. Рекомендации по определению потерь воды из крупных оросительных каналов. Киев: Ротапринт УкрНИИГиМ, 1979. 19 c.

4. Руководство по гидрологическим прогнозам. Вып. 2. Ленинград: Гидрометеоиздат, 1989. $246 c$.

5. Михайлов Ю.О., Розгон В.А., Крученюк В.Д. Рекомендації. Метрологія. Витрата води у відкритих водотоках. Зареєстровано ХДНДІМ, Харків: 2003.

6. Киенчук А.Ф. Водораспределение на оросительных системах. Киев: Урожай, 1989. 176 с. 


\section{References}

1. Mykhaylov, Yu. O., Kosharovs'ka, I. L., \& Popovych, A. V. (2003) Parametrychna nadiynist' vodorozpodilu u Pivnichno-Kryms'komu kanali PParametric reliability of water distribution in the North Crimean channel]. Melioratsiya i vodne hospodarstvo, 89, 66-71. [in Ukrainian].

2. Kovalenko, P. I., \& Mykhaylov, Yu. O. (2000). Ratsional'ne vykorystannya vody pry zroshenni [Rational use of water during irrigation]. Kyiv: Ahrarna nauka. [in Ukrainian].

3. Rekomendatsyy poopredelenyyu poter'vodyyzkrupnykhorosytel'nykhkanalov. [Recommendations for determining the loss of water from large irrigation canals]. (1979). Kyev: Rotaprynt UkrNYYHyM. [in Ukrainian].

4. Rukovodstvo po hydrolohycheskym prohnozam. [Guide to Hydrological Forecasts]. (2nd ed.). (1989). Lenynhrad: Hydrometeoyzdat. [in Russian].

5. Mykhaylov, Yu. O., Rozhon, V. A., \& Kruchenyuk, V. D. (2003). Rekomendatsiyi. Metrolohiya. Vytrata vody u vidkrytykh vodotokakh. [Recommendations. Metrology. Water consumption in open water streams]. Kharkiv. [in Ukrainian].

6. Kyenchuk, A. F. (1989). Vodoraspredelenye na orosytel'nykh systemakh [Water distribution on irrigation systems]. Kyev: Urozhay. [in Russian].

И.Л. Гончарук

Параметническая надежность материкового участка Северо-Крымского канала

Рассмотрены особенности режима работы материковой части Северо-Крымского канала в условиях прекрачения подачи воды в Крым используя водомерныте свойства подпорно-регулируюших та водовыпускных гидротехнических сооружений. Приведены результаты расчетов параметрической надежности распределения воды в канале. Проблемы чентрализованного управления расходами воды на гидротехнических сооружениях в условиях, не предусмотренных проектом и пути их решения.

\section{Parametric reliability of the continental part of the North-Crimean canal}

\section{I.L. Goncharuk}

The features of the operating mode of the continental part of the North-Crimean canal under conditions of stopping the water supply to the Crimea using the water-measuring properties of the supporting-regulating and discharge waterworks are considered. The results of calculations of the parametric reliability of water distribution in the canal are given. Problems of centralized management of water flow in hydraulic structures under conditions not covered by the project and ways to solve them are considered as well. 